\title{
Seasonality of Monomachus Klug (Hymenoptera, Monomachidae) in the Biological Reserve of Duas Bocas, Espírito Santo State, Brazil ${ }^{1}$
}

\author{
Celso Oliveira Azevedo ${ }^{2}$ \\ Hélio Sá Santos ${ }^{2}$
}

\begin{abstract}
A survey of Monomachidae species was carried out in an area of Atlantic rain forest of the Biological Reserve of Duas Bocas, Espírito Santo State, Brazil between September, 1996 and August, 1997. Two species of Monomachus Klug, 1841, M. fuscator Perty, 1833 and M. eurycephalus Schletterer, 1890 were collected from May to September. Both species are typical of winter time and showed the same pattern of seasonality.
\end{abstract}

KEY WORDS. Hymenoptera, Monomachidae, Monomachus, seasonality, Neotropi$\mathrm{cal}$

Monomachus Klug, 1841, is the main genus of Monomachidae (Hymenoptera, Proctotrupoidea), with austral-disjunct distribution (NAUMANN 1985), with 3 species from the Australian region and 11 from the Neotropical region, as listed by JOHNSON (1992).

Little is known about Monomachus, the last paper regarding its world fauna being ScHulz (1911), where a key was included to the genera and species of the family.

Adults of monomachid wasps prefer cool, moist, forest habitats (NAUMANN 1985). Few biological data suggest that Monomachus is parasitoid of larva and pupa of Diptera, Stratiomyiidae (RIEK 1970).

Our main goal was to get information on the seasonality of the genus Monomachus in an area of Atlantic rain forest of the Biological Reserve of Duas Bocas, Espírito Santo State, Brazil in order to compare it to the pattern of Australian species.

\section{MATERIAL AND METHODS}

The survey was conducted in the Biological Reserve of Duas Bocas, in Cariacica County, State of Espírito Santo, Brazil (20 $\left.19^{\circ} \mathrm{S}, 40^{\circ} 30^{\prime} \mathrm{W}\right)$. This reserve lies about 20 kilometers far from the seashore in a straight line and covers an area of 2,910 hectares, with an altitude ranging from 250 to 640 meters. The main vegetation is Atlantic rain forest. The investigation was undertaken entirely in the period of September 1996 through August 1997 along a trail of a secondary Atlantic rain forest area, preserved for 50 years, edged by a reservoir fed with water from the Pau Amarelo, Naia-Assu and Panelas streams, about 50 to 100 meters away.

1) Supported by Pró-reitoria de Pesquisa e Pós-graduação, Universidade Federal do Espírito Santo.

2) Departamento de Biologia, Universidade Federal do Espirito Santo. Avenida Marechal Campos 1468, Maruípe, 29040-090 Vitória, Espírito Santo, Brasil.

E-mail: cazevedo@npd.ufes.br and hss@npd.ufes.br 
The sampling method chosen was sweeping, because it had proved the best method for collecting general Hymenoptera parasitoid fauna during a pilot collection carried out before the main investigation. We made use of a Rose Engineering net and performed 12 samples, once a month. Each sample entailed 24 sets of sweeping with one minute each, disregarding any time spent in removing insects from the net. Sweeping of vegetation was as random as possible reaching from the ground level to approximately 1.5 meters above the ground level, between 10:00 and 14:00 hours.

The material was deposited at the Entomological Collection of the Universidade Federal do Espírito Santo (UFES).

Although the sampling were conducted from September 1996 to August 1997, we have organized the figure 1 in an annual sequence of months in order better to show the seasonality of these wasps.

\section{RESULTS}

A total of 122 specimens was collected during the survey, being 22 of them Monomachus fuscator Perty, 1833 and the remaining, Monomachus eurycephalus Schletterer, 1890. Considering the total sampling effort as taking 288 minutes, 0.42 specimens per minute were collected.

All specimens here collected are exclusively males. We have tried unsuccessfully to get females with yellow pan trap, Malaise trap and window trap during the day, and with Shannon trap and CDC light trap during the nights. We have also tried to get them by means of an extra sweeping of the vegetation, but again unsuccessfully. We have also looked actively for the specimens on the leaves and barks of the plants, removing leaves off the ground with the same result.

The specimens were collected only from May to September (Fig. 1). The populations of both species increased very fast initially. They are more abundant in June. After this, the number of specimens decreased more slowly up to September or October. Although Monomachus eurycephalus was found to be abundant, both species showed the same pattern of seasonality (Fig. 1).

\section{DISCUSSION}

The amount of 122 specimens represents $1.46 \%$ of the total of Hymenoptera parasitoids collected, ranking 12 among the 30 families surveyed in number of specimens collected (AZEVEDO \& SANTOS 2000).

Although there is high temperature in the State of Espírito Santo all year long, it usually goes down a little bit from the end of May up to the beginning of October. This period corresponds to the period of occurrence of Monomachus in the reserve.

According to NAUMANN (1985), adults of Australian Monomachus occur in humid habitats and tend to fly during the cooler months, as M. antipodalis Westwood, 1874, or those species from higher regions have a longer summer flight period, as M. hesperius Naumann, 1985. 


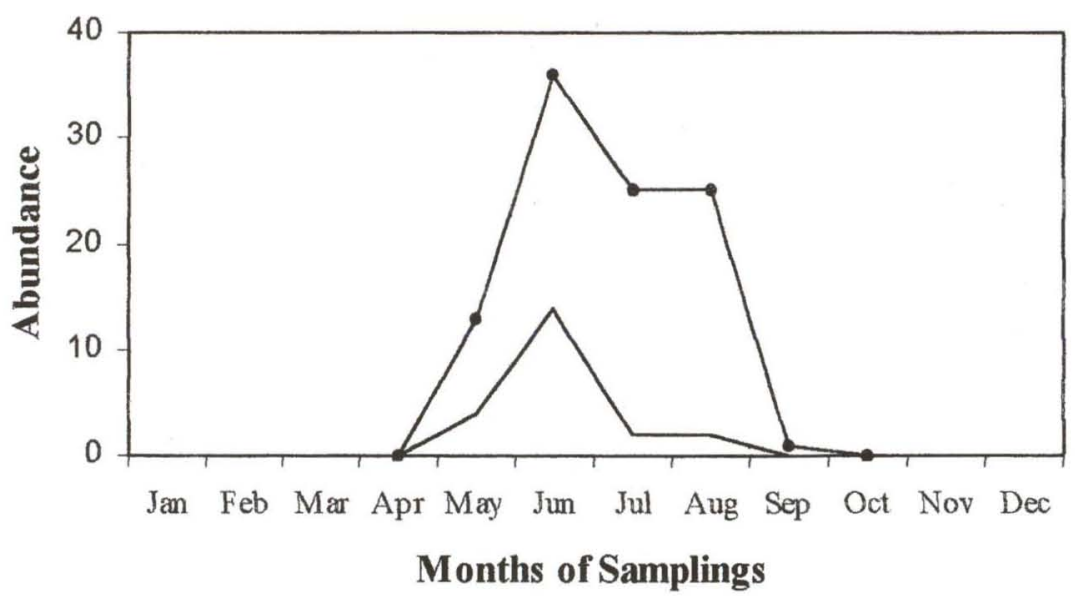

\section{$\longrightarrow$ Monomachus fuscator $\longrightarrow$ Monomachus lateralis}

Fig. 1. Seasonal distribution of Monomachus fuscator and M. eurycephalus in the Biological Reserve of Duas Bocas, Espírito Santo, Brazil.

A single species of Monomachus is present in Costa Rican forest at altitudes between 1,000 and 1,600 meters (MASNER 1995), whereas he also reported having collected numerous males in Venezuelan cloud forests between 8:00 and 9:00 hours in August 1992, and no more specimens were found by 10:00. Although our samples were restricted to between 10:00 and 14:00 hours, we were able to see many specimens of them in activity from 8:00 up to 17:00 hours.

The number of 122 specimens collected seems to be low, but it is expressive to Monomachidae and to sampling effort employed. Perioto (pers. com.) has got only one specimens of Monomachus in a survey of hymenopteran parasitoids in an area of Brazilian savannah in São Paulo State in 1989 using five different kinds of traps. We have got 0.71 specimens by minute of sweeping in May, 2.08 in June, 1.12 in July and August, and 0.04 in September. In addition, our study has focused the seasonality rather abundance.

Our results, compared to those got by NAUMANN (1985) and MASNER (1995), lead us to believe that the Monomachidae species such as the Australian species and these Neotropical species are typical from the area with a cool temperature. Therefore, they can be specially collected in high altitude areas during winter time.

ACKNOWLEDGMENTS. To Dr. L. Musetti from Ohio State University for the identification of the species, Instituto de Defesa Agropecuária e Florestal by the authorization of the use of the Reserve, Pró-reitoria de Pesquisa e Pós-graduação/UFES by the financial support grant number $074 / 96$ and R.S. Neves who revised carefully the English version. 


\section{REFERENCES}

Azevedo, C.O. \& H. S. Santos. 2000. Perfil da fauna de himenópteros parasitóides (Insecta, Hymenoptera) em uma área de Mata Atlântica da Reserva Biológica de Duas Bocas, Cariacica, ES Brasil. Bol. Mus. Biol. Mello Leitão, n.s., 11/12: 117-126.

JoHNSON, N.F. 1992. Catalog of world species of Proctotrupoidea, exclusive of Platygastridae (Hymenoptera). Mem. Amer. Entomol. Inst. 51: 1-825.

MASNER, L. 1995. The proctotrupoid families, p. 209-246. In: P.E. Hanson \& I.D. Gauld (Eds). The Hymenoptera of Costa Rica. London, Oxford Univ. Press, Nat. Hist. Mus., 893p.

NaUmanN, I.D. 1985. The Australian species of Monomachidae (Hymenoptera, Proctotrupoidea), with a revised diagnoses of the family. Jour. Aust. Entomol. Soc. 24: 261-274.

RIEK, E. 1970. Hymenoptera (wasps, bees, ants), p. 867-959. In: CSIRO. The Insects of Australia. Carlton, Melbourne Univ. Press, 1029p.

Schulz, W.A. 1911. Systematische Uebersicht der Monomachiden. Acta I Internat. Cong. Entomol.: 405-422.

Recebido em 18.IV.2000; aceito em 10.V.2001. 